\title{
NUTRITION OF YOUNG LEMON PLANTS IN THE OPEN FIELD
}

\section{Sultonov Kamolitdin Sadriddinovich ${ }^{1}$, Nortojiev Bobosher Sheralievich ${ }^{2}$ Yusupova Kamola Qosimovna ${ }^{3}$}

\author{
${ }^{I}$ Doctor of Agricultural Sciences, Professor of the Department of Fruit Growing and Viticulture, \\ Tashkent State Agrarian University, Tashkent, Uzbekistan \\ ${ }^{2}$ Independent Researcher, Assistant of the Department of Fruit Growing and Viticulture, \\ Tashkent State Agrarian University, Tashkent, Uzbekistan \\ ${ }^{3}$ First-Year Master Student in the Specialty of Fruit Growing, \\ Tashkent State Agrarian University, Tashkent, Uzbekistan
}

\begin{abstract}
The article provides scientific data on the study of optimal norms and timing of leaf feeding in the care of young lemon seedlings in the open field. The care of young lemon seedlings in the open field focuses on the rapid growth of branches, enlargement of leaf surface and leaf activity. Due to the additional nutrition of the leaves, the growth and development of young lemon seedlings is accelerated, the leaf surface is cleaned of dust, which has a positive effect on the metabolism of the leaves, the process of respiration and photosynthesis in the leaves. As a result, young lemon seedlings grow well in the short term and are formed as seedlings ready for planting in the main area.

KEYWORDS: lemon, seedling, seedling, twig, leaf surface, open area, air temperature, relative humidity, fertilizer, suspension, photosynthesis.
\end{abstract}

\section{INTRODUCTION}

In recent years, the demand for citrus fruits and their by-products (juice, marmalade, candied, essential oils, etc.) in Uzbekistan has increased significantly. In this regard, the approach to growing lemons in the country has changed radically [1].

Therefore, the Resolution of the President of the Republic of Uzbekistan dated February 19, 2020 No. PD-4610 "On additional measures for further development of the lemon industry" [1] further expansion of subtropical crops, in particular citrus fruits in the country, the tasks of radically improving the state of existing fields, the organizing the order of their reproduction and cultivation on a scientific basis are being solved [2].

In the country, lemon seedlings are grown mainly in special facilities and (in the trenches), greenhouses.
In the experiment, the technology of obtaining one-yearold lemon seedlings in the open field and obtaining high-quality seedlings resistant to adverse climatic conditions in the short term was developed [3].

Faxriddinov M.Z [3] emphasizes that any seedling propagated from cuttings has many positive features, such as genetically identical to the parent plant, physiological and anatomical general, rapid recovery of the part lost due to aging or external environment. V.I. Tsulaya and U. Eshankulova [5] recommended that the Tajik climate lemon bushes are irrigated up to 25 times during the growing season in climatic conditions. N.Z.Faxrutdinov [4].

In climatic conditions of Uzbekistan, it is recommended watering lemon trees in greenhouses 2325 times during the growing season. F.V.Sadikova [2] found that lemon trees in greenhouses in the city of Ufa 


\section{SJIF Impact Factor 2021: 8.013| ISI I.F.Value:1.241| Journal DOI: 10.36713/epra2016 \\ ISSN: 2455-7838(Online) \\ EPRA International Journal of Research and Development (IJRD)}

Volume: 6 | Issue: 12 | December 2021

- Peer Reviewed Journal

in the Southern Urals give good results when irrigated 13-15 times a year [5].

\section{MATERIALS AND METHODS}

In the experiment, we used one-year-old young shoots of the Meyer variety of lemon as the object of study. The experiments were conducted in AprilOctober 2021 at the experimental site of the Information Consultation Center (Extension center) of the Tashkent State Agrarian University, Qibray district, Tashkent region. The total area of the study was $200 \mathrm{~m}^{2}$ and was conducted in 4 replications.

During the study, phenological observations and biometric measurements (leaf feeding, seedling height, branch formation and number of leaves) were performed on young lemon seedlings.

\section{RESULTS AND DISCUSSION}

Our research has shown that in the care of young lemon seedlings in the open field, feeding them not only from the root but also from the leaf of the seedlings is an important agro-technical measure. The norms and favorable terms of feeding from leaves, as well as feeding and watering seedlings between rows during the growing season were studied.

As a result of insufficient supply of young seedlings with nutrients, the seedlings may lack quality. Including; lack of phosphorus makes the leaves of the plant slightly reddish in spring and summer, resulting in slower photosynthesis. As a result of potassium deficiency, the leaves of the plant become brown, slightly curled, which causes the seedlings to get sick quickly. Nitrogen deficiency sharply reduces the rate of rapid growth of young seedlings; the leaves become pale green, almost yellowish in color.

This leads to the death of young seedlings. In determining the norms of feeding young seedlings of lemons through the leaves, it is necessary to pay attention to the growth phases of lemon seedlings, their planting scheme, level of development, leaf surface area. When feeding the seedlings through the leaves, it is recommended to use nitrogen, phosphorus, potassium fertilizers to prepare the suspension.

The growth and development of seedlings accelerates in May-June. During this period, it is desirable to supplement the seedlings with nutrients. One or two days after watering the seedlings are watered in the second half of the day, use a mixture of suspensions from 1.6-1.8 to 2.7-3.2\%. Consumption rate of mineral fertilizers (physically) consumption per 100 $\mathrm{m}^{2}$ of seedling area (liters). Application period $0.18 \%$ concentrate $0.48 \mathrm{~kg}$ carbamide 30 liters in the $1^{\text {st }}$ decade of May, 0.3,\% concentrate $0.3-0.4 \mathrm{~kg}$ carbamide +0.6 $\mathrm{kg}$ superphosphate 30 liters May 3 and in the $1^{\text {st }}$ decade of June, $0.4 \%$ concentrate $0.2 \mathrm{~kg}$ of carbamide $+0.9 \mathrm{~kg}$ of superphosphate $+0.7 \mathrm{~kg}$ of potassium chloride, 30 liters in August-September.

Prepared solutions are required to spray the leaves and twigs of seedlings in the morning and evening, when the weather is cool, in order to feed the leaves, depending on the developmental stages of seedlings. When a solution of carbamide (carbamide) is sprayed, its nitrogen is absorbed through the leaves of seedlings, 8-10 times faster than fertilizer applied to the soil. Therefore, the growth and development of young seedlings accelerate. The leaves grow healthy; respiration and photosynthesis are well performed. At the same time the epidermal layer of the leaf matures and enters the infection of various diseases, the process of exposure to harmful insects is sharply reduced.

During the growing season, young shoots have 3-4 growth phases. In April-May, rapid growth of branches was observed. In the 3rd decade of June 2021 and in July, there were also times when the daytime air temperature exceeded $46-48^{\circ} \mathrm{C}$ at some points during the day. At this temperature the growth of seedlings almost stopped. The air temperature rose sharply and the relative humidity fell by $18-20 \%$. The high temperature caused the top parts of the leaves and twigs of some seedlings to dry out. In such cases, fresh water was sprayed on the leaves in the evening.

As a result of timely agro-technical measures and adequate feeding of seedlings from the leaves in the second half of August the development of new leaves was observed on the dried branches. At the same time on the branches laying the foundation for the formation of buds that will bear fruit the following year.

Table 1.

The norm of mineral fertilizer consumption per $100 \mathrm{~m}^{2}$ during the growing season of young seedlings 2021

\begin{tabular}{|c|c|c|c|}
\hline \multirow{2}{*}{ Feeding times } & \multicolumn{3}{|c|}{ Consumption of mineral fertilizers (physical) } \\
\cline { 2 - 4 } & Carbamide & Superfos & Potassium chloride \\
\hline May & 0,4 & 0,3 & 0,2 \\
\hline June & 0,6 & 0,5 & 0,3 \\
\hline July & 0 & 0,2 & 0,1 \\
\hline August & 0,4 & 0,9 & 0,4 \\
\hline September & 0,3 & 0,7 & 0,3 \\
\hline
\end{tabular}




\section{EPRA International Journal of Research and Development (IJRD)}
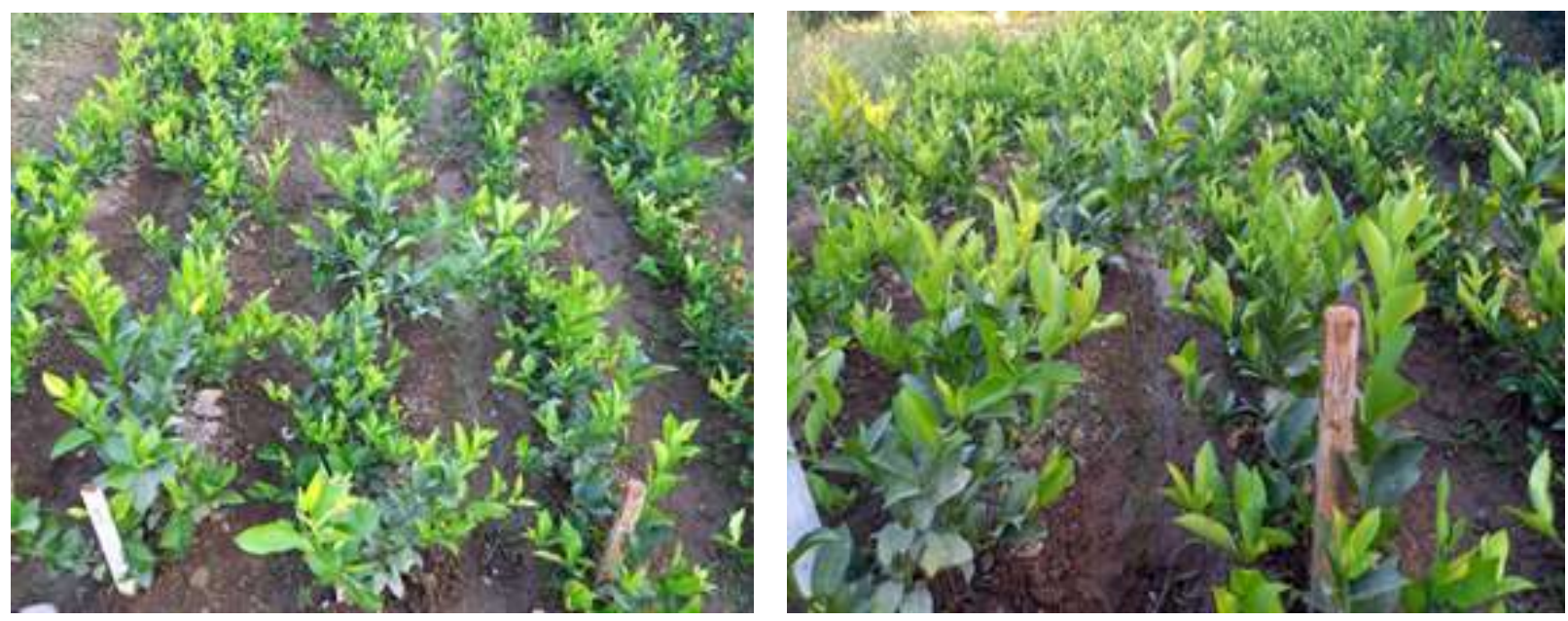

Fig 1. Experimental lemon plant seedlings

\section{CONCLUSION}

In the cultivation of seedlings, supplementary feeding of young seedlings from the leaves saves nutrients, the plant feeds well on the leaves, and in short term achieved to get healthy vigorous seedlings.

As a result of feeding the seedlings with leaves from the open field, the seedlings develop rapidly, in a short time to obtain well-developed, vigorous seedlings, as well as optimal standards of nutrients and timing of feeding was determined.

It was found that additional feeding from the leaves at the same time as feeding the seedlings from the root gave positive results and was effective.

\section{REFERENCES}

1. Degree of the President of the Republic of Uzbekistan No. PD-4610 dated February 19, 2020 "On additional measures for further development of the lemon industry."

2. Sadikova F.V. (2004). Lemon. Practical recommendations growing lemon plant indoor. Ufa, pp. 14-15.

3. Fakhriddinov M.Z. (2016). Mysterious industries of lemon growing - "National Encyclopedia of Uzbekistan Publishing House", Tashkent.

4. Fakhrutdinov N.Z. (1991). When receiving lemon seedings. Agriculture of Uzbekistan, №10. pp. 30-33.

5. Tsulaya V.I., Eshankulov U. (1965). Citrus fruits in Tadjikistan. Publishing House: "Ifron", Dushanbe. 